VOX PATRUM 25 (2005) t. 48

Jarosław JAKIELASZEK

(Warszawa, UW)

\title{
„NESCIT QUO FLECTERE PUPPEM" (Corippi Johan. I 273)* HIPOTEZA KONTAMINACYJNA
}

Rozpoznanie i uznanie obecności struktur pochodzących z kontaminacji składniowej $\mathrm{w}$ tekstach późnołacińskich było jednym $\mathrm{z}$ istotnych elementów zasadniczej zmiany w podejściu do języka poklasycznego, jaka nastąpiła dzięki pracom skandynawskiej szkoły filologicznej. Szereg tradycyjnie emendowanych miejsc odzyskało dzięki temu właściwe brzmienie i wyjaśnienie, równocześnie zaś ich analiza stylistyczna została wyzwolona $\mathrm{z}$ objęć normatywnej gramatyki szkolnej (szkolnej, nie zaś klasycznej - obraz języka autorów klasycznych również uległ dzięki temu istotnym zmianom). Wśród struktur wyjaśnianych hipotezą kontaminacyjną znalazło się wiele struktur z podrzędną frazą zdaniową, w tym konstrukcje względne i frazy pytajne zawisłe pozbawione ośrodka finitywnego, zastąpionego formą niefinitywną - bezokolicznikiem:

(1) „nescit quo flectere puppem"1

W opinii szeregu badaczy ${ }^{2}$ konstrukcja taka jest rezultatem kontaminacji składniowej struktur z zawisłą frazą zdaniową pytajną i zawisłych fraz względnych ${ }^{3}$.

" Flavius Cresconius Corippus, żyjący w poł. VI wieku w okolicach Kartaginy w Afryce, biskup-poeta, autor ułożonego ok. $550 \mathrm{r}$. (w VIII księgach, 6667 wierszy) poematu epicznego: Johannis seu de bellis Lybicis (CPL 1515; ed. M. Petschening: MGHaa III 2, 1-109, przedruk: PLS IV 998-1128, lub ed. J. Digle - F.R.D. Goodyear, Johannidos seu de bellis Libycis libri VIII, Cambridge 1970). o wojnie Rzymian z Wandalami afrykańskimi, por. H. Hofmann, Corippus as a patristic author, VigCh 43 (1989) 361-377; DPAC I 784-785; R. Dodi, Corippo poeta della Romanitas africana, „Aevum” 60 (1986) 111-119; V. Zarini, La préface de la Johannide de Corippe. Certitudes et hypothèses, REAug 32 (1986) 74-91; R. Jakobi, Kritisches und Exegetisches zur Johannis des Coripp., „Hermes” 117 (1989) 95-119; J. Urban Andres, Concordantia in Flavii Corippi Joannida, Hildesheim 1993; Ch. Tomasi Moreschini, Realtà della storia e retorica dell'impero nella "Johannis» di Corippo, „Athenaeum" 90 (2002) 161-185; tenże, La "Johannis» corippea: ricupero e rescrittura dei modelli classici e cristiani, „Prometheus” 27 (2001) 250-276.

1 Corippus, Johannis I 273, PLS IV 1006.

2 Por. np. D. Norberg, Syntaktische Forschungen, Uppsala 1943, 259n; E. Löfstedt, Syntactica II, Lund 1956, 171 oraz ogólne uwagi o znaczeniu przypisywanym kontaminacji, zob. E. Löfstedt, Late Latin, Oslo 1959, 20.

${ }^{3}$ Niektórzy znaczną rolę przypisują także względom czysto morfologicznym, tj. morfologicznej 
Struktura w (1) staje zatem w jednym rzędzie obok jednoznacznie pochodzących $\mathrm{z}$ kontaminacji składniowej przykładów na obecność ośrodka niefinitywnego we frazie zdaniowej wprowadzonej przez konektor (spójnik lub relator) typowo konotujący w sposób konieczny strukturę z ośrodkiem finitywnym:

(2) a. ,[...] placuit nobis sancto spiritu suggerente et domino per visiones multas et manifestas admonente, ut quia hostis nobis inminere praenuntiatur et ostenditur, colligere intra castra milites Christi et examinatis singulorum causis pacem lapsis dare, immo pugnaturis arma suggerere" ${ }^{\text {. }}$.

b. „Certi sumus frater carissime, te quoque nobiscum pari voto congaudere quod nos habito consilio utilitatibus ecclesiae et paci magis consulentes, omnibus rebus praetermissis et iudicio dei servatis, cum Cornelio episcopo nostro pariter et cum universo clero pacem fecisse"

Typową sytuacją, w której następuje taka kontaminacja składniowa, jest wystąpienie frazy przerywającej linearny porządek struktury i oddzielającej konektor od konotowanej frazy zdaniowej; ściśle rzecz biorąc, struktura w (2a) zawiera zawisłą frazę zdaniową quia ... ostenditur w rozbudowanej warstwie $\mathrm{C}$ a la Rizzi poniżej Force $\mathrm{P}^{6}$ (gdzie usytuowany jest konektor $u t$ ), tj. jest skutkiem operacji przenoszącej lub bezpośredniego przyłączenia (w zależności od rodzaju frazy zdaniowej) ${ }^{7}$. W (2b) występuje sekwencja fraz

niejednoznaczności form koniunktiwu imperfecti i infinitiwu praesentis, por. np. F. Blatt, Die lateinischen Bearbeitungen der Acta Andreae et Matthiae apud antropophagos, Giessen 1930, 168 i 193.

${ }^{4}$ Cyprianus, Epistola 57, 5, 1, CCL 3B, 308-309.

5 Cyprianus, Epistola 53, CCL 3B, 250.

${ }^{6}$ Por. L. Rizzi, The fine structure of the left periphery, w: L. Haegeman (ed.), Elements of grammar, Dordrecht 1997, 281-337, oraz prace usytuowane w związanym z tą propozycją nurcie „kartograficznym”, jak: G. Cinque (ed.), Functional structure in DP and IP. Cartography of syntactic structures, vol. 1, Oxford 2002, L. Rizzi (ed.), The structure of CP and IP. The cartography of syntactic structures, vol. 1, Oxford 2003, A. Belletti (ed.), Structures and beyond. The cartography of syntactic structures, vol. 1, Oxford 2004. Poniżej przyjmujemy podstawowe założenia Programu Minimalistycznego, zob. N. Chomsky, Derivation by phase, w: M. Kenstowicz (ed.), Ken Hale: a life in language, Cambridge 2001, 1-50; tenże, A minimalist program for linguistic theory, w: K. Hale - S.J. Keyser (eds.), The view from Building 20. Essays in Honor of Sylvain Bromberger, Cambridge 1993, 1-52; tenże, Beyond explanatory adequacy, w: A. Beletti (ed.), Structures and beyond: the cartography of syntactic structures, Oxford 2004, 104-131: tenze, Minimalist inquiries: the framework, w: D.M.R. Martin - J. Uriagereka (eds.), Step by step, Cambridge 2000, 89-155; tenże, The Minimalist Program, Cambridge 1995; tenże, Three factors in language design, „Linguistic Inquiry” 36 (2005) 1-22.

${ }^{7}$ Całkowicie odrębną grupę stanowią przykłady na pozorną integrację składniową wtrąconej frazy zdaniowej:

(1) Ps-Quintilianus, Declamationes minores 263, 2: „Non ut opinor ipsum saltem dicere ausurum".

(2) Ps-Quintilianus, Declamationes minores 331, 16: „Non ut opinor eius te futurum impudentiae ut hoc contendas".

Przypadki takie przypuszczalnie zawierają faktycznie elipsę całej frazy zdaniowej, z pozostawieniem jedynie przyłączonego zdania „wtrąconego" jako realizowanego w komponencie PF, por. A. 
przyłączonych w warstwie C (z niefinitywnym ośrodkiem składniowym), również zaburzająca linearną sekwencję konektor - konotowana fraza zdaniowa. Naruszenie własności konotacyjnych jest w takich przypadkach prawdopodobnie niczym więcej niż błędem realizacji wspomaganym własnościami verbum regens, które wykazuje łączliwość zarówno z konstrukcją bezokolicznikową, jak i z frazą finitywną; hipoteza kontaminacji składniowej jest w takich przypadkach zasadna, przykłady zaś tego typu można traktować jako elementy języka potocznego o tyle, o ile za cechę definicyjną języka literackiego w odniesieniu do języków klasycznych można przyjąć eliminację błędów realizacji. $\mathrm{Z}$ takim zastrzeżeniem właśnie rozumieć trzeba np. uwagę J. Schrijnena i C. Mohrmann ${ }^{8}$ o vulgäre Mischkonstruktion ut cum Infinitivo jako komentarz do (2a). Stanowisko Schrijnena i Mohrmann w kwestii rozumienia fragmentu nie jest zresztą jednoznaczne, obok bowiem przytoczonej uwagi zaliczają oni ten sam fragment do grupy tzw. ut expletivum, traktując sekwencję ut quia jako całość, $z$ ut pozbawionym znaczenia i będącym jedynie pustym semantycznie wzmocnieniem właściwego konektora quia (podobnie W.A. Baehrens ${ }^{9}$ i L. Bayard ${ }^{10}$. Niejasna jest również motywacja Diercksa, który, pozostawiając bez zmian tekst rękopisów, przytacza w aparacie krytycznym obie wypowiedzi Schrijnena i Mohrmann nie dokonując wyboru analizy. Hipoteza kon-taminacyjna, tj. zmiana struktury w sytuacji przerwania linearnej ciągłości między konektorem i TP konotowanej frazy zdaniowej przy opcjonalnym charakterze łącz-liwości verbum regens jest jednak najtrafniejsza, jak dobitnie wskazują analogiczne przykłady, w których nie można uczynić struktury bardziej „regularną” (tak bowiem w istocie należy traktować przyjęcie ut expletivum w (2a) przez założenie obecności pleonastycznego $u t$ lub innego konektora, jak w (2b) i analogicznych przykładach na frazę bezokolicznikową przy obecności konektora konotującego TP z ośrodkiem finitywnym, por. np.

(3) ,[...] sciturus quia si quid secus accesserit tuo neglectui modis omnibus imputari" 11 .

Tsubomoto - J. Whitman, A type of Head - in Situ construction in English, „Linguistic Inquiry” 31 (2000) 176-183; M. Guimarães, Syntactic Amalgams as dynamic Constituency in Top-Down Derivations, w: M. van Koppen - J. Sio - M. de Vos (eds.), Proceedings of ConSOLE X, Leiden 2001, 63-78, $\mathrm{z}$ dyskusją możliwości analizy podobnych struktur; o przykładach łacińskich (z założeniem kontaminacji) zob. zwłaszcza: E. Löfstedt, Vermisschte Studien zur lateinischen Sprachkunde und Syntax, Lund 1936, 153-155; tenże, Syntactica, II, Lund 1956, 165-166.

${ }^{8}$ Por. J. Schrijnen - C. Mohrmann, Studien zur Syntax der Briefe des hl. Cyprian, vol. II, Nijmegen 1937, 98.

9 Por. W.A. Baehrens, Beiträgen zur lateinischen Syntax, Leipzig 1912, 419.

${ }^{10}$ Por. L. Bayard, Le Latin de Saint Cyprien, Paris 1902.

11 Gregorius Magnus, Epistolae II 35; por. też D. Norberg, Syntaktische Forschungen, Uppsala $1943,252 \mathrm{nn}, \mathrm{z}$ licznymi przykładami. 
Hipoteza ut expletivum zaciemnia rzeczywistą naturę zjawiska w wielu przykładach w ten sposób analizowanych ${ }^{12}$.

Przytoczone powyżej przykłady można scharakteryzować jako błędy realizacji językowej. Zmiana struktury składniowej następuje w ściśle określonych warunkach, skąd wrażenie językowej produktywności zjawiska, którego nie należy jednak mylić z sygnałami rzeczywistej zmiany syntaktycznej lub morfologicznej. Względna częstość kontaminacji tego typu wynika z charakteru tekstów (w dużo większym stopniu pozostawiających składniki sermo cotidianus rozumianego jako faktyczna realizacja językowa, niż teksty autorów klasycznych), zmian w zakresie łączliwości niektórych czasowników (w szczególności, ekspansji finitywnych fraz zdaniowych wprowadzanych przez konektory quod, quia, quoniam w miejsce struktur niefinitywnych) i zmiany norm poprawności stylistycznej. (1) jest jednak przykładem zupełnie innego rodzaju.

W (1) nie następuje zmiana struktury analogiczna do (2a) lub (2b). Wprawdzie nescire wykazuje także łączliwość $\mathrm{z}$ frazą bezokolicznikową, jednak - gdy brak w niej podmiotu (pomijając ewentualną elipsę) - interpretowane jest odmiennie, nie ma też ekwiwalencji semantycznej z nescire $\mathrm{z}$ a.c.i. - jak wiadomo, nescire wykazuje typową alternację między zjawiskiem kontroli i ECM:

(4) a. Nescit vertere puppem.

b. Nescit se vertere puppem.

(1) nie może pochodzić z kontaminacji żadnej ze struktur w (4) z finitywną frazą zdaniową quo vertat puppem, nie tylko dlatego, że tzw. zdania pytajne wymagają ośrodka finitywnego, ale także dlatego, że struktury w (4) pozbawione są odcienia modalnego jednoznacznie charakteryzującego (1) i całą klasę należących tu struktur:

(5) Sed quid est aliud quam nescire quid dicere, et tamen non posse nisi maledicere $?^{13}$

(6) Si nostra vera et vestra falsa sunt, olim quid dicere non habetis ${ }^{14}$.

(7) Quid ab eis acceperunt, si non habebant quid dare? ${ }^{15}$

(8) Habes unde vincere, parata sunt adminicula, incipe proeliari, dominus tecum $^{16}$.

(9) Non est ergo quid agere ${ }^{17}$.

12 Por. zwłaszcza Baehrens, Beiträgen, s. $415 \mathrm{nn}$, z wieloma przykładami, częściowo nietrafnymi także z powodów krytycznych. Nie oznacza to zanegowania zjawiska w ogóle, a jedynie wyznaczenie mu węższych granic; należy przy tym mieć na uwadze możliwość zmiany odcienia semantycznego, zob. np. Bayard, Le Latin de Saint Cyprien, s. 164.

13 Augustinus, Contra litteram Petiliani II 51, 118, PL 43, 300C.

14 Tamże III 59, 72, PL 43, 388A.

15 Augustinus, Psalmus contra partem Donati 220, PL 43, 30A.

16 Arnobius Iunior, Commentarii in Psalmum 123, PL 53, 526A.

17 Augustinus, In epistolam Joannis ad Parthos 9, 9, PL 35, 2051B) 
(10) Invenimus autem homines aliquando pigros dicentes, verum est, domine, verum est; non est quid dicere ${ }^{18}$.

Zdania takie semantycznie ekwiwalentne są zdaniom $\mathrm{z}$ frazą zawisła $\mathrm{z}$ ośrodkiem finitywnym o zachowanym odcieniu modalnym lub zdaniom, w których czasownik modalny jest wprost wyrażony we frazie bezpośrednio zawisłej od verbum regens:

(11) Nescio quid dicam.

(12) Nescio quid dicere debeam (possim).

Obecność elementu modalnego w interpretacji semantycznej, obligatoryjna w (1) i analogicznych przykładach, odróżnia wyraźnie takie struktury od (4). Zasadne jest zatem założenie obecności modalnego elementu w (1). Należy przy tym zauważyć, że interpretacja modalna struktury bezokolicznikowej podlega pewnym ograniczeniom: dostępna jest interpretacja deontyczna (zatem cała grupa należących tu relacji dostępności modalnej, w tym buletyczna), niemożliwa jest zaś interpretacja epistemiczna, w odróżnieniu od fraz zdaniowych z ośrodkiem finitywnym, dopuszczających obie interpretacje ${ }^{19}$.

Struktury bezokolicznikowe $w$ łacinie dzielą się podstawowo na dwie grupy: zawierające specyfikację semantycznego aspektu (tzw. accusativus cum infinitivo) i zawierające specyfikację niekonkretną aspektu semantycznego interpretowanego domyślnie jako imperfektywny (typ possum dicere) ${ }^{20}$. Wymogi morfologiczne i linearyzacyjne determinują specyficznie łacińską postać obu struktur: pierwsza grupa zawiera mocne wystąpienie (S-OCC) podmiotu w pozycji specyfikatora AspP, uniemożliwiając jego przeniesienie

${ }^{18}$ Augustinus, Sermo 359, 8, PL 39, 1596B.

19 O rodzajach interpretacji modalnej czasowników lacińskich por. zwłaszcza A.M. Bolkestein, Problems in the description of modal verbs, Assen 1980, z licznymi przykładami i obszerną dyskusją zagadnienia $w$ ramach tzw. gramatyki funkcjonalnej. Na różnice $w$ dostępności interpretacji modalnych fraz bezokolicznikowych analogicznych do (1) i odpowiednich fraz finitywnych w językach nowożytnych zwraca uwagę obfita literatura przedmiotu, zob. m.in. R. Izvorski, NonIndicative wh-Complements of Possessive and Existential Predicates, w: P.N. Tamanji - K. Kusumoto (eds.), Proceedings of NELS 28, GLSA, Amherst 1998; A. Grosu - F. Landman, Strange relatives of the third kind, "Natural Language Semantics” 6 (1998) 125-170; R. Bhatt, Covert Modality in Non-Finite Contexts, PhD thesis, Philadelphia 1999, University of Pennsylvania; A. Grosu, The syntax-semantics of modal existential wh-constructions, w: O.M. Tomić (ed.), Balkan Syntax and Semantics, Amsterdam 2004, 405-438, z dalszą literaturą.

${ }^{20}$ O semantycznej interpretacji cech czasu i (zewnętrznego) aspektu, por. np. A. von Stechow, The Janus Face of aspect. Manuscript, Tübingen 2001; E. Gerö - A. von Stechow, Tense in time: the Greek Perfect, w: R. Eckhardt - K. von Heusinger - C. Schwarze (eds.), Words in time: diachronic Semantics from diffrent points of view, Berlin - New York 2003, 251-294; A. von Stechow, On the Proper Treatment of Tense. Manuscript, Tübingen 1995; A. Kratzer, More structural analogies between pronouns and tenses, w: D. Strolovich - A. Lawson (eds.), Proceedings of SALT VIII, New York 1998, 36-54. 
do frazy nadrzędnej, skąd obligatoryjność podmiotu leksykalnego (ewentualnie pro) w zawisłej frazie zdaniowej. Grupa druga zawiera jedynie słabe wystąpienie podmiotu w pozycji początkowego Scalenia, tj. wejścia frazy nominalnej w przestrzeń derywacyjną, a równocześnie pozbawiona jest cech kotwiczących interpretację czasową frazy nominalnej, skąd nie tylko możliwość, ale i konieczność przeniesienia do frazy nadrzędnej. Własność mającego pełną specyfikację ośrodka aspektu Asp różni struktury greckie i łacińskie: greckie struktury zawierają słabe wystąpienie podmiotowej frazy nominalnej w pozycji specyfikatora AspP, skąd możliwość przeniesienia do frazy nadrzędnej (tzw. nominativus cum infinitivo przy verba dicendi et intelligendi w activum).

Pełna architektura frazy zdaniowej zawiera jednak w warstwie funkcjonalnej nie tylko ośrodki składniowe związane z kategoriami czasu i aspektu, ale także ośrodki związane $\mathrm{z}$ kategorią modalności. Umiejscowienie ich wynika z fazowej natury struktury syntaktycznej w rozumieniu minimalistycznym; $\mathrm{w}$ analizie proponowanej przez J. Butlera ${ }^{21}$, umożliwiającej otrzymanie wielu własności przewidzianych $w$ modelu kartograficznym ${ }^{22}$, fraza zdaniowa budowana jest $\mathrm{z}$ faz składających się każdorazowo z ośrodka leksykalnego, ośrodka funkcjonalnego i ośrodka kwantyfikacyjnego, w którym miejsce mają także operatory modalności. Ich obecność thumaczy m.in. interpretacyjne właściwości tzw. infinitivus finalis: warstwa $\mathrm{C}$ zawiera w nich operator modalny (ze składnikiem futuryczności), odpowiedzialny za modalną interpretację konstrukcji:

(13) quoniam venit iudicare terram (Ps 95, 13)

Obecność operatora modalnego wyjaśnia także brak morfologii peryfrastycznej dla wyrażenia futuryczności w tzw. zdaniach celowych właściwych: ich warstwa C obligatoryjnie zawiera operator modalny, niezbędny dla otrzymania właściwej interpretacji (w przeciwieństwie do tzw. zdań dopełnieniowych, tj. fraz zdaniowych w pozycji argumentowej). Ograniczenia dostępności różnych interpretacji modalnych w (1) sugerują, że operator modalności winien być umiejscowiony znacznie niżej - bezpośrednio nad frazą werbalną vP, poniżej ośrodka aspektowego, jako zamknięcie fazy wyrażającej własności zdarzenia ${ }^{23}$.

${ }^{21}$ Por. J. Butler, Phase structure, Phrase structure and Quantification, PhD thesis, Heslington 2004, University of York.

22 Por. G. Cinque, Adverbs and Functional Heads, Oxford 1999.

${ }^{23}$ Podejście takie zawiera więc elementy analizy wielofunkcyjnej składników struktury składniowej, uzależniając interpretację od miejsca wystąpienia w strukturze, w sposób znany także gramatyce tradycyjnej w odniesieniu do elementów mających powierzchniowe wykładniki morfologiczne, por. np. C. Lefebvre - D. Massam, Haitian Creole syntax: a case for DET as head, „Journal pf Pidgin and Creole Languages" 3 (1988) 213-243; N. Duffield, Aspects of Vietnamese Clausal Structure: separating Tense from Assertion. Manuscript, McGill University, Montreal 2004. 
Interpretacja epistemiczna, dla której konieczna jest obecność zmiennych czasowych we frazie zdominowanej przez operator, jest wtedy niedostępna ${ }^{24}$.

Morfologicznym wykładnikiem struktur niefinitywnych we wszystkich przypadkach, w których ośrodek aspektu ma specyfikację niekonkretną, jest w lacinie tzw. infinitivus praesentis (poza przypadkami czysto morfologicznej asymilacji oraz strukturami, w których obecność innych elementów wymusza odmienną postać morfologiczną, np. włączenie operatora rezultatywności wewnątrz frazy werbalnej lub struktury przyimkowej ponad frazą bezokolicznikową; ośrodek czasu ma w omawianych strukturach, podobnie, jak we frazach zawisłych zgodnych z consecutio temporum, również specyfikację niekonkretna). Operator modalny pełni istotną funkcję także w kotwiczeniu interpretacji fraz nominalnych, należy zatem oczekiwać wystąpienia frazy nominalnej podmiotu w pozycji specyfikatora ModP, w przypadku łaciny wystąpienia słabego, nie zamykającego drogi do dalszych operacji przenoszących (niezbędnych dla skutecznej linearyzacji łańcucha). Struktury modalne typu reprezentowanego $\mathrm{w}(1)$, podobnie, jak tzw. infinitivus finalis w (13), proponujemy zatem analizować jako powstające w wyniku sukcesywnych operacji przenoszących (tradycyjna analiza postulowałaby obecność PRO). Zjawisko kontroli redukowane jest wtedy do operacji przenoszących, zgodnie z szeregiem propozycji teoretycznych $^{25}$. Zauwaźyć należy, że operacje przenoszące następują w tych przypadkach $z$ frazy zawisłej w pozycji argumentowej (także w (13), gdzie zawisła fraza bezokolicznikowa występuje w pozycji argumentu ośrodka aplikatywnego), linearyzacja powstającego łańcucha jest zatem możliwa bez dodatkowych założeń (poza słabym wystąpieniem frazy nominalnej podmiotu w pozycji specyfikatora ModP we frazie zawisłej $)^{26}$.

Struktura w (1) nie jest zatem, zgodnie z zaproponowaną analizą, rezultatem kontaminacji. W przeciwieństwie do szeregu innych, pozornie analogicz-

${ }^{24}$ Por. szczególowo Butler, Phase structure, Phrase structure, s. 138nn. Zauważyć należy, że takie umiejscowienie operatora modalnego występuje także $w$ innych formach werbalnych, w szczególności w tzw. participium necessitatis, o którym zob. choćby E. Risch, Gerundivum und Gerundium: Gebrauch im klassischen und älteren Latein: Entstehung und Vorgeschichte, Berlin New York 1984, z tradycyjnego punktu widzenia i z analizą generatywną D.G. Miller, Gerund und Gerundive in Latin, „Diachronica” 17 (2000) 293-349.

${ }_{25}$ Por. w szczególności N. Hornstein, Movement and control, „Linguistic Inquiry” 30 (1999) 69-96; tenże, Move! A minimalist Theory of Construal, Oxford 2001; tenże, On control, w: R. Hendrick (ed.), Minimalist Syntax, Oxford 2003, 6-81; C. Boeckx - N. Hornstein, Reply to control is not movement, „Linguistic Inquiry” 34 (2003) 269-280; C. Boeckx - N. Hornstein, Movement under control, „Linguistic Inquiry” 35 (2004) 431-451, częściowo w kontrpolemice z tezami, jakie wysuwa I. Landau: tenże, Elements of control. Structure and meaning in infinitival constructions, Dordrecht 2000; tenże, Movement Out of Control, „Linguistic Inquiry” 34 (2003) 470-498; tenże, The Scale of finiteness and the resistant aspects of control. Manuscript, Beer-Sheva 2004.

${ }^{26}$ Por. także Grosu, The syntax-semantics of modal existential wh-constructions, s. 405-438, który dokonuje analizy składniowej i semantycznej struktur typu non habeo quod dicere, tj. wprowadzanych przez zaimki względne, postulując m.in. obecność ośrodka modalnego we frazie zawisłej. 
nych konstrukcji, nie polega ona na zmianie konotowanej frazy w sytuacji opcjonalności jej rodzaju, charakteryzując się własnościami zasadniczo różnymi od domniemanych $\mathrm{w}$ hipotezie kontaminacyjnej źródeł. Nie jest zatem niezrozumiałe, czemu struktury takie wykazały się żywotnością, jakiej nie należałoby się spodziewać po prostych błędach performancji. Pojawieniu się struktur w (1) nie towarzyszą żadne zmiany struktury składniowej. System języka na poziomie składni i semantyki pozostaje niezmienny. Wyjaśnienia wymaga jednak nieobecność takich struktur w zabytkach literackich aż po okres późnołaciński. Znajduje ona uzasadnienie nie tylko w szczególnym charakterze źródeł. Nie ma potrzeby domniemywać, że język potoczny realizował konstrukcje egzemplifikowane w (1) znacznie wcześniej, a jedynie puryzm języka literackiego eliminował je skutecznie. Tendencje języka prozy klasycznej są przecież $\mathrm{w}$ istocie jedynie konsekwencją ogólnołacińskich tendencji żywych w języku potocznym - skłonności do ujednoznacznienia wykładników morfologicznych przez jak najściślejsze związanie ich z konkretnymi strukturami składniowymi i semantycznymi, eliminacji alternatywnych specyfikacji typu wystapienia w identycznych strukturach etc. Frazy zdaniowe wprowadzane przez konektor są na gruncie łacińskim jednoznacznie powiązane $\mathrm{z}$ mocnym wystąpieniem frazy nominalnej podmiotu, skąd ich blokujący charakter dla dalszych operacji przenoszących ( $\mathrm{z}$ wyjątkiem operacji typu A) wobec niemożliwości linearyzacji łańcucha, i specyfikacją co najmniej ośrodka aspektowego, której w (1) brak. Obecność konektora nie jest sama z siebie przyczyną niemożliwości przeniesienia do frazy nadrzędnej - odpowiedzialna za efekt blokady jest natura wystąpienia i budowa powstającego łańcucha. Pouczające jest porównanie $\mathrm{z}$ sytuacją na gruncie greckim, gdzie wystąpienia frazy nominalnej podmiotu są słabe, co umożliwia przeniesienie nie tylko $\mathrm{z}$ frazy pozbawionej konektora, ale również $\mathrm{z}$ fraz wprowadzanych spójnikowo, jak w zdaniach $\mathrm{z}$ toore ${ }^{27}$. Struktury w (1) $\mathrm{w}$ istocie pozbawione sa specyfikacji czasowo-aspektowej, jedynym ośrodkiem zawierającym (słabe) wystąpienie frazy nominalnej podmiotu powyżej vP jest ModP. Natura wystąpienia podmiotu w specyfikatorze ModP nie zmienia się w momencie pojawienia się struktur w (1); zmiany następują natomiast $w$ module morfologicznym, ściślej rzecz biorąc - w przekształceniu struktur składniowych na reprezentacje morfologiczne. Morfologia infinitivus praesentis staje się wykładnikiem stosowanym szerzej, niż w okresie wcześniejszym, skąd np. akceptowalność frazy bezokolicznikowej zawisłej od przy-imków. Co więcej, specyfikacja wystąpienia w specyfikatorze ośrodka aspektowego w tzw. a.c.i. staje się niestabilna, skutkiem czego obok tradycyj-

${ }^{27}$ Por. dalej Boeckx - Hornstein, Movement under control, s. 431-452; F. Marušić, CP under control. Manuscript, Stony Brook 2003, z dalszą literatura. Zjawisko to jest ważnym kontrargumentem przeciw hipotezom uzależniającym możliwość operacji przenoszących od nieobecności warstwy C. 
nego accusativus cum infinitivo pojawiają się niezależne od wpływu greki (choć dzielące $\mathrm{z}$ nią relewantną cechę) frazy bezokolicznikowe $\mathrm{z}$ przeniesieniem frazy podmiotu $\mathrm{z}$ pozycji specyfikatora ośrodka aspektowego zawierającego pełną cechę semantyczną (innymi słowy, wystąpienie frazy nominalnej staje się opcjonalnie słabe). Zmiany te skutkują akceptowalnością operacji przenoszących także w (1) mimo obecności konektorów - niezależnie od tego, czy jest to tzw. zaimek pytajny, czy tzw. zaimek względny ${ }^{28}$. Jako fraza niezawisła (zatem pozbawiona konektora) analogiczne frazy bezokolicznikowe, $z$ niekonkretną specyfikacją czasu i aspektu semantycznego, jedynie $z$ ośrodkiem modalnym interpretowanym deontycznie, morfologia infinitivus praesentis występuje już w okresie klasycznym jako infinitivus dubitationis ${ }^{29}$ :

(14) Quid enim? Sedere totos dies in villa? ${ }^{30}$

Jedyną zmianą diachroniczną jest zmiana pozostająca poza obszarem składni i semantyki, w istocie całkowicie „zewnętrzna”. Stabilność systemu języka jest w tym przypadku zgodna $z$ hipotezą inercyjności składni, wpisując się $\mathrm{w}$ inne procesy diachroniczne wykazujące stabilność systemu syntaktycznego $^{31}$. Hipoteza kontaminacyjna nie wyjaśnia ani składni i semantyki omawianych struktur, ani faktycznych mechanizmów ich powstania, ani ich późniejszej stabilności w systemie językowym.

Wspomnieć należy wreszcie przywołany już wyżej (n. 2) argument dotyczący względów morfologicznych rozumianych wąsko jako homofonia niektórych form bezokolicznikowych i finitywnych (coniunctivus imperfecti). Po powyższych wywodach winno być jasne, że nie należy przypisywać temu aspektowi znaczenia w powstaniu struktur w (1). Parafrazując hasło „morfologia nie jest

${ }^{28}$ Typ non habeo quod dicam zawiera zatem w pozycji argumentowej bezpośrednio frazę $\mathrm{CP}$, por. Grosu, The syntax-semantics of modal existential wh-constructions, s. 405-438.

${ }^{29}$ Niejawny element modalny jest obecny także w infinitvus admirantis vel indignantis, zob. $\mathrm{H}$. Menge, Lehrbuch der lateinischen Syntax und Semantic, Darmstadt 2000 (ristamp. bearb. Th. Burkard - M. Schauer) s. 696n i analizę: K. Grohmann, Null Modals in Germanic (and Romance): Infinitival Exclamatives, „Belgian Journal of Linguistics” 14 (2000) 43-61; R. Etxepare - K.K. Grohmann, Towards a syntax of adult Root Infinitives, w: D. Cresti - T. Satterfield - C. Tortorra (eds.), Proceedings of LSRL 29, Amsterdam 2000. Tu jednak pojawia się ośrodek aspektowy ze specyfikacją semantyczną skąd dopuszczalność frazy nominalnej podmiotu i obecność bezokoliczników innych niż infinitivus praesentis, sam zaś ośrodek modalny usytuowany jest przypuszczalnie wyżej w strukturze składniowej.

${ }^{30}$ Cicero, Ad Atticum XII 44, 2.

31 O hipotezie inercyjności składni w procesie diachronicznym por. G. Longobardi, Formal Syntax, diachronic minimalism and etymology: the history of French „Chez”, „Linguistic Inquiry” 32 (2001) 275-302; zob. też uwagi G. Ferraresi - M. Goldbach, Some reflections on inertia: infinitive complements in Latin, w: N. Baumgarten - C. Böttger - M. Motz - J. Probst (eds.), Úbersetzen, interkulturelle Komunikation, Spracherwerb und Sprachvermittlung - das Leben mit mehreren Sprachen. Festschrift für Juliane House, „Zeitschrift für Interkulturellen Fremdsprachenunterricht" 8 (2003) 240-251 o accusativus cum infinitivo $\mathrm{z}$ tego punktu widzenia. 
siłą sprawczą składni”32, dodać można: morfologia nie jest siłą sprawczą zmiany diachronicznej, a jedynie jej odbiciem. Podobna homofonia nie jest także np. źródłem powstania tzw. bezokoliczników osobowych, choć niejednoznaczność wykładników morfologicznych może odgrywać pewną rolę w destabilizacji systemu morfologicznego ${ }^{33}$.

Zmiana diachroniczna egzemplifikowana przez bezokolicznikowe struktury modalne jest bardzo $w$ istocie powierzchowna (i powierzchniowa), dotyczy jedynie akceptowalności morfologicznej postaci struktur syntaktycznych dostępnych łacinie w sposób niezmienny stulecia wcześniej. Do ich pojawienia

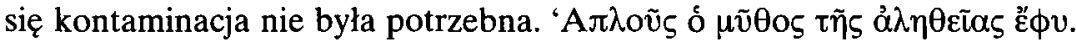

\title{
„NESCIT QUO FLECTERE PUPPEM” (CORIPPI JOHAN. I 273). THE CONTAMINATION HYPOTHESIS
}

\author{
(Summary)
}

The paper examines a Late Latin construction consisting of a relative or an interrogative pronoun followed by a bare infinitive. It has been often proposed that the syntactic structure of such sentences results from a contamination of two distinct clause types. This paper proposes an analysis in terms of the Minimalist framework, rejecting the traditional approach and explaining syntactic and semantic properties of the structure on the basis of mechanisms independently motivated for other Latin structures. The surface shape of such clauses is argued to result from changes in morphological parameters. The analysis provides therefore support for the thesis that language change involves primarily the morphological module, which remains the main locus of diachronic and synchronic variation.

${ }^{32}$ Por. np. J.D. Bobaljik, Realizing Germanic inflection: why morphology does not drive syntax, „Journal of Comparative Germanic Linguistics” 6 (2002) 129-167.

${ }^{33} \mathrm{O}$ bezokolicznikach osobowych zob. ostatnio zwl. I. Sitaridou, The Synchrony and diachrony of Romance Infinitives with Nominative Subjects, PhD thesis, Manchester 2002; D.G. Miller, Where do conjugated infinitives come from?, „Diachronica” 20 (2003) 45-81, z obszerną dyskusją zagadnienia. 